\title{
Influence of Emissions from the Stationary Heat Sources upon the Atmospheric Precipitation Pollution with Inorganic Nitrogen in the Sevastopol Region
}

\author{
A. V. Varenik \\ Marine Hydrophysical Institute of RAS, Sevastopol, Russian Federation \\ alla.varenik@mhi-ras.ru
}

Purpose. Boiler houses are currently an indispensable and integral element of infrastructure in any settlement. They supply us with hot water; provide heating of living quarters, working areas etc. However, functioning of each stationary heat source has a significant drawback: harmful emissions to the atmosphere. These emissions via the atmospheric precipitations fall on the underlying surface contaminating water, especially coastal ecosystems, soils etc. The aim of the work is to study the effect of such emissions from the stationary heat sources upon pollution of the air and atmospheric precipitations with inorganic nitrogen.

Methods and Results. To evaluate possible effect of emissions from the boiler houses upon the atmospheric precipitation pollution in Sevastopol, the results of chemical analysis of the nitrogen oxidized forms' concentration in the precipitation samples were scrutinized, and the increased number of the boiler houses, their types and, hence, growth of their emissions in 2015-2018 were assessed.

Conclusions. According to the data provided by the Office of Federal State Statistics Service for Sevastopol, in 2016 the number of the boiler houses increased sharply that resulted in growth of the nitrogen oxides emissions to the atmosphere. At the same time, our data showed a two-fold increase of the inorganic nitrogen flow with the atmospheric precipitations in a cold period. Having been analyzed, the oxidized nitrogen concentration in precipitations and the nitrogen oxides' emissions from the boiler houses in Sevastopol, demonstrated close correlation. However, in 2018, despite the increased number of the boiler houses, a significant decrease in emissions from the stationary heat sources was observed; it is confirmed by our data on the inorganic nitrogen flow with the atmospheric precipitations.

Keywords: atmospheric precipitation, boiler houses, air pollution, nitrogen emissions.

Acknowledgements: the author is thankful to the staff of the Marine Hydrometeorological Station "Sevastopol" for sampling the atmospheric precipitations and providing the data on the meteorological conditions attending the precipitations. The research was carried out within the framework of theme No. 0827-2018-0004 and the RFBR project No. 18-05-80028 Hazardous phenomena "Studies and scaling of water dynamics and biogeochemical processes in development of oxygen deficit and sulfidic conditions in coastal areas of Crimea and Kerch Strait”.

For citation: Varenik, A.V., 2020. Influence of Emissions from the Stationary Heat Sources upon the Atmospheric Precipitation Pollution with Inorganic Nitrogen in the Sevastopol Region. Physical Oceanography, [e-journal] 27(3), pp. 257-265. doi:10.22449/1573-160X-2020-3-257-265

DOI: 10.22449/1573-160X-2020-3-257-265

(C) A. V. Varenik, 2020

(C) Physical Oceanography, 2020

\section{Introduction}

In recent decades human activity have led to significant pollution of all components of the environment, such as atmosphere, hydrosphere and lithosphere. One of the principal sources of atmospheric air pollution in large cities is smallscale power generation facilities - heating boiler houses operating on various types of fuel: solid, liquid and gaseous ${ }^{1}$, - as well as motor vehicles. Both of these sources

${ }^{1}$ Akomova, T.A. and Khaskin, V.V., 2012. [Man - Economy - Biota - Environment]. Moscow: YUNITY-DATA, 495 p. Available at: https://drive.google.com/file/d/1_rLKDwH8455r9vkkWR92ur-waZGe8s1/view [Accessed: 06 June 2020] (in Russian). 
supply various pollutants to the atmosphere of cities, including inorganic nitrogen compounds.

Nitrogen oxides $\mathrm{NO}_{\mathrm{x}}$ are the main toxic components produced during the fossil fuel combustion. They are about 10 times more dangerous than carbon oxides [1].

In [2], the authors take up the position that in 2015, among the estimated pollutants in Belo Horizonte (Brazil), taking into account all the sources, nitrogen oxide emissions were maximum and amounted to 305 t/year. This pollutant emission is closely related to combustion processes. Nitrogen oxide emissions in Belo Horizonte occurred mainly in industrial boiler houses, biogas plants and metallurgical plants.

The volume of pollutants entering the atmosphere is directly related to the quality and quantity of fuel used, as well as to the waste gas systems used (or absence of such systems). For fuel and energy systems (FESs) running on gaseous fuels, the main pollutants are nitrogen oxides $\left(\mathrm{NO}_{\mathrm{x}}\right)$ and carbon monoxide (CO); for FESs burning liquid fuel - nitrogen oxides, sulfur dioxide $\left(\mathrm{SO}_{2}\right)$, carbon monoxide and fuel oil ash; for solid fuel thermal power plants - nitrogen oxides, sulfur dioxide, carbon monoxide and solids².

According to [3], in the Tomsk Region, the highest values of nitrogen oxide emissions are observed during the fuel oil (ranging from 2 to $25 \mathrm{t} /$ year) and natural gas (up to $15 \mathrm{t}$ /year) combustion. The amount of nitrogen emissions from any of the solid fuel boiler houses does not exceed $100 \mathrm{~kg} /$ year. The amount of emissions of harmful substances is totally proportional to the boiler room capacity.

The authors of [4] calculated that the volumes of emissions of nitrogen oxides during the hot water production significantly vary in the warm and cold periods. Thus, in summer, the emissions are $539 \mathrm{mg} / \mathrm{s}$ and in the heating season 3,175 mg/s.

According to [5], one of the most serious problems in Poland is also air pollution from boiler plants. This is mainly due to the preference for coal as a fuel for boiler houses, the use of old low-efficiency boilers and the continuous heating period in this country (at least 5 months), due to the country location in a temperate climate zone [5]. In this work, the author shows that the amount of nitrogen oxides entering the atmosphere is maximum when using coal (470 mg/kW'h). The most environmentally friendly fuel is gas: emissions of nitrogen oxides from gas boiler houses are an order of magnitude lower than those from coal-fired ones, and are $30 \mathrm{mg} / \mathrm{kW} \cdot \mathrm{h}$.

The energy and environmental aspects of heat energy production play an important role in the context of the sustainable development of each country. In the environmental context, it becomes important to minimize emissions of pollutants into the atmosphere resulting from the use of renewable energy sources [6].

2 All-Russia Thermal Engineering Institute, 2013. [Standards for Specific Emissions of Pollutants into the Atmosphere from Boiler Plants of HPSs]. Available at: https://vti.ru/files/public/uchebno-metod_posobie-k_soglasheniyu_0665.pdf [Accessed: 06 June 2020] (in Russian). 
January 6, 2012, Directive 2010/35/ $\mathrm{EU}^{3}$ entered into force, revising the standards for the main pollutants generated by burning fossil fuels in thermal installations. The limit values of the nitrogen oxides concentration for gas burning boiler plants, according to the standards valid after 01.01.2016, are $100 \mathrm{mg} / \mathrm{m}^{3}$. Emission limits for boiler houses ${ }^{2}$ using other fuels are shown in Tab. 1.

Table 1

\section{Extreme values of nitrogen oxides for solid and liquid fuels}

\begin{tabular}{|c|c|c|c|}
\hline \multirow{2}{*}{$\begin{array}{l}\text { Boiler plant heat capacity, } \\
\text { MW }\end{array}$} & \multicolumn{3}{|c|}{$\begin{array}{l}\text { Maximum concentration limit, } \mathrm{mg} / \mathrm{m}^{3} \text {, of nitrogen oxides } \\
\text { in emissions in case a boiler house applies }\end{array}$} \\
\hline & coal and other solid fuels & \begin{tabular}{|l|} 
biomass and peat \\
\end{tabular} & liquid fuel \\
\hline $50-100$ & $\begin{array}{l}300 * \\
400 * *\end{array}$ & 250 & 300 \\
\hline $100-300$ & 200 & 200 & 150 \\
\hline$>300$ & $\begin{array}{l}150 \\
200 * *\end{array}$ & 150 & 100 \\
\hline
\end{tabular}

* Coal.

** Brown coal.

Consequently, the city's boiler-houses changing over to gaseous fuels should have a positive effect on atmospheric air quality, since there are no emissions of sulfurous substances and mercury when burning natural gas. Nitrogen oxides per unit of energy are also released several times less than when using oil, petrol or $\mathrm{coal}^{4}$.

In [7], the authors analyzed emission reduction strategies using the UISIS-PNP model by changing the fuel type used or installing technologies to reduce air emissions. For example, changing over from coal to natural gas or biomass can cut by half $\mathrm{SO}_{2}$ emissions. Changing over to biomass provides an added benefit of reduced $\mathrm{CO}_{2}$ and $\mathrm{NO}_{\mathrm{X}}$ emissions. The installation of special SCR (Selective Catalytic Reduction) technology permits to achieve reduction of $\mathrm{NO}_{\mathrm{X}}$ emissions from wood by $75 \%$, and from coal, natural gas and residual oil - by $90 \%$.

Impurities contained in atmospheric air are washed out by atmospheric precipitation. On the one hand, it cleans the urban atmosphere, and on the other can negatively affect the ecological state of the underlying surface.

\footnotetext{
${ }^{3}$ Directive 2010/35/EU of the European Parliament and of the Council of 16 June 2010 on transportable pressure equipment and repealing Council Directives 76/767/EEC, 84/525/EEC, 84/526/EEC, 84/527/EEC and 1999/36/EC (Text with EEA relevance). Official Journal of the European Union, L 165, 53, pp. 1-18. doi:10.3000/17252555.L_2010.165.eng

${ }^{4}$ Kraetskaya, O.F. and Prokopenya, I.N., 2014. [Heat Power Engineering Ecology]. Minsk: BNTU, 107 p. (in Russian).
} 
For example, inorganic nitrogen that falls into coastal waters with atmospheric precipitation can make a significant contribution to the intensity of algae bloom, which, in turn, enhances eutrophication and the appearance of hypoxic zones of coastal waters in the warm period, as well as a change in the classic Redfield ratio for nitrogen, phosphorus and carbon [8,9]. Given that the necessary task of the marine environment quality monitoring is to control the spread of various pollutants [10], it is important to have an idea of the sources of pollutants, including atmospheric precipitation [11].

The present study was aimed to assess the possible influence of the operation of boiler plants in Sevastopol, one of the most developed cities in the coastal zone of Crimea, on the content of inorganic nitrogen compounds in precipitation.

\section{Materials and Methods}

In 2015-2018 atmospheric precipitation sampling was carried out by the employees of Marine Hydrometeorological Station (MHS) Sevastopol on the Cape Pavlovskiy in Sevastopol in accordance with the Atmospheric Pollution Control Guidelines ${ }^{5}$. With the beginning of precipitation, the following weather conditions that could have a significant influence on precipitation pollution [12]: wind speed and direction, air temperature, relative humidity and the precipitation amount, were recorded. Samples were taken in a wet-only precipitation collector, that eliminated the introduction of foreign impurities into it in the interval between precipitation. MHS Sevastopol operates on a round-the-clock basis, which allows for the correct sampling procedure and to obtain a more accurate time of the precipitation start, as well as the values of meteorological conditions at the time of precipitation start.

Since the main forms of nitrogen contained in the emissions of boiler plants are nitrogen oxide and dioxide, it was precisely the oxidized forms - nitrates and nitrites - that were analyzed in the work. Chemical analysis of precipitation samples was carried out in the Department of Biogeochemistry of the Sea of Marine Hydrophysical Institute of RAS. The amount of nitrates and nitrites was determined by the method of reduction of nitrates to nitrites using cadmium treated on an automatic analyzer of nutrients AutoAnalyzer $A A I I^{6}$ by Bran+Luebbe (Switzerland). The precipitation amount (flow) of oxidized forms of nitrogen was calculated as the product of the total concentration of nitrites and nitrates in the precipitation samples and the precipitation amount per area unit over a certain period.

Data on the number of boiler houses in Sevastopol in 2015-2018 operating on various types of fuel, volumes and characteristics of emissions from stationary pollution sources were obtained from the data of the Territorial Authority of the Federal State Statistic Service for Sevastopol (Krymstat). Since 2018, data on emissions of pollutants into the Sevastopol air has been provided by the Main Department of Natural Resources and Ecology of Sevastopol (Sevprirodnadzor).

5 The USSR Goskomgidromet, 1991. [RD 52.04.186-89.1991, Atmospheric Pollution Control Guidelines]. Introduced 1991-07-01. Moscow, 694 p. (in Russian).

6 SEAL Analytical, 1996. AutoAnalyzer Applications: AutoAnalyzer Method No. G-172-96 Nitrate and Nitrite in Water and Seawater. Buffalo Grove, Il: Bran Luebbe, Inc., 9 p. Available at: http://www.environmentdata.org/archive/dtcavon:204/OBJ/preview.pdf [Accessed: 03 July 2020]. 


\section{Results and Discussion}

In total, over the period from 2015 to 2018, 333 precipitation samples were taken and analyzed. The concentration of nitrates and nitrites was determined in each sample.

Data on nitrogen oxide emissions from boiler houses in 2014-2018 in Sevastopol are presented in Tab. 2.

Table 2

Emissions of pollutants from the stationary heat sources to the atmosphere in Sevastopol during the considered period

\begin{tabular}{l|c|c|c|c|c}
\hline \multicolumn{1}{c|}{ Pollutants } & $\mathbf{2 0 1 4}$ & $\mathbf{2 0 1 5}$ & $\mathbf{2 0 1 6}$ & $\mathbf{2 0 1 7}$ & $\mathbf{2 0 1 8}$ \\
\hline All pollutants & 1462 & 1709 & 4397 & 5377 & 3034 \\
$\begin{array}{l}\text { Including: } \\
\left.\quad \text { nitrogen oxide (in terms of } \mathrm{NO}_{2}\right)\end{array}$ & 222 & 378 & 752 & 884 & 195 \\
\hline
\end{tabular}

According to Tab. 2, emissions of nitrogen oxides into the atmosphere sharply increased in 2016 and almost quadrupled by 2017: from 222 tons in 2014 to 884 tons in 2017. In 2018, emissions of oxides significantly decreased and returned to the 2014-year level.

One of the atmospheric air pollution indicators is the nitrates and nitrites content in precipitation, since it is precipitation that clears the atmosphere of impurities contained in it. For this reason, the oxidized nitrogen concentration data in atmospheric precipitation (Tab. 3) should correlate with air pollution resulting from the operation of the city's boiler houses.

Table 3

Concentration and flow of the oxidized nitrogen forms in the atmospheric depositions during the considered period

\begin{tabular}{l|c|c|c|c}
\hline \multicolumn{1}{c|}{ Characteristic } & $\mathbf{2 0 1 5}$ & $\mathbf{2 0 1 6}$ & $\mathbf{2 0 1 7}$ & $\mathbf{2 0 1 8}$ \\
\hline $\begin{array}{l}\text { Concentration during a heating period, } \\
\mu \text { mol/L: }\end{array}$ & & & & \\
$\begin{array}{l}\text { - average } \\
\text { - maximum }\end{array}$ & $\begin{array}{l}49.22 \\
172.19\end{array}$ & $\begin{array}{l}68.07 \\
302.63\end{array}$ & $\begin{array}{l}73.52 \\
376.33\end{array}$ & $\begin{array}{c}50.26 \\
177.25\end{array}$ \\
\hline $\begin{array}{l}\text { Flow, mmol } / \mathrm{m}^{2} \cdot \text { year: } \\
\text { - annual } \\
\text { - during heating period }\end{array}$ & 11.52 & 17.99 & 19.53 & 11.75 \\
& 5.96 & 10.12 & 11.84 & 7.22 \\
\hline
\end{tabular}

Analyzing the Tab. 3 data, it can be noted that in 2016, compared with the previous year, the average concentration of oxidized nitrogen in atmospheric 
precipitation increased 1.3 times and almost 2 times its maximum concentration, and its flow during the heating period increased 1.7 times. In the same year, according to Tab. 2, the amount of $\mathrm{NO}_{2}$ emissions from stationary sources of Sevastopol almost doubled. In 2018, nitrogen oxide emissions, according to Sevprirodnadzor, decreased by 4.5 times compared to 2017, approximately to the level of 2014. Moreover, the average and maximum concentrations of oxidized forms of nitrogen in atmospheric precipitation are the same as during the heating period, their flow decreased more than one and a half times and almost returned to the level of 2015.

The variation of nitrogen emissions (in terms of $\mathrm{NO}_{2}$ ) into the atmosphere from stationary sources and the flow of oxidized forms of nitrogen with precipitation is shown in the figure below.

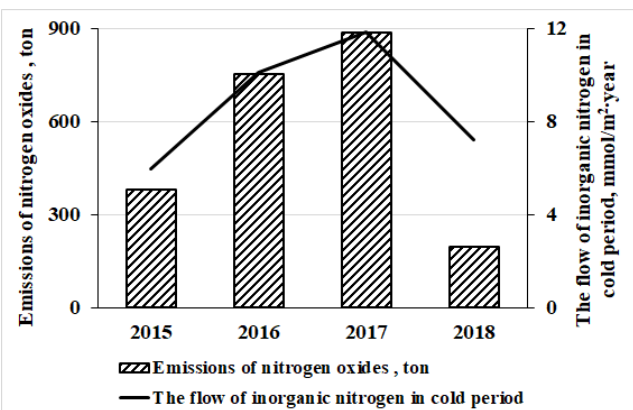

$a$

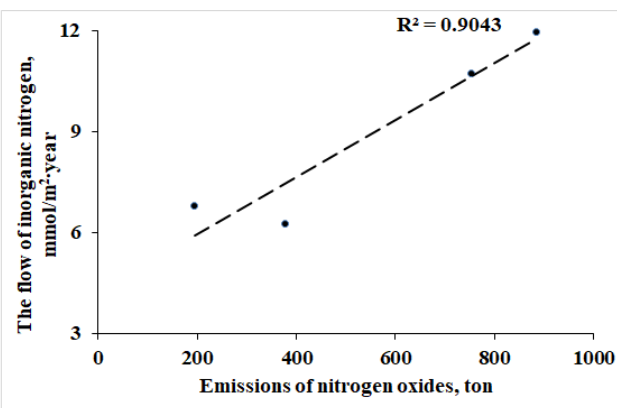

$b$

F i g. Inter-annual variations of the nitrogen oxides' emissions and the nitrogen oxidized forms (nitrite and nitrate nitrogen) flow with atmospheric depositions $(a)$; the relationship between the nitrogen emissions to the atmosphere and the inorganic nitrogen flow with atmospheric depositions in Sevastopol $(b)$

According to Fig. b, with an increase in the amount of nitrogen oxides emissions into the atmosphere from stationary sources, the flow of oxidized forms of nitrogen with atmospheric precipitation also increases.

The emission amount from boiler plants is affected by both the fuel type used in the boiler room and the purification degree of exhaust gases. There is no data on the purification degree of exhaust gases from all boiler houses in Sevastopol in our disposal. However, the number of boiler houses divided by the fuel type used in the considered period can be traced.

Tab. 4 shows data of the Federal State Statistic Service Office for the Republic of Crimea and the city of Sevastopol (Krymstat) and the Government of Sevastopol on the number of boiler houses in Sevastopol in 2014-2018. (total number and ranged by fuel type). 
Number of boiler houses in Sevastopol and dynamics of fuel consumption during the period under study based on the Crimea statistics

\begin{tabular}{l|r|r|r|r|r}
\hline \multicolumn{1}{c|}{ Characteristic } & $\mathbf{2 0 1 4}$ & $\mathbf{2 0 1 5}$ & $\mathbf{2 0 1 6}$ & $\mathbf{2 0 1 7}$ & $\mathbf{2 0 1 8}$ \\
\hline $\begin{array}{l}\text { Total number of boiler houses } \\
\quad \text { Including: }\end{array}$ & 116 & 118 & 133 & 135 & 143 \\
- on solid fuel & 21 & 22 & 31 & 30 & 29 \\
- on liquid fuel & 3 & 3 & 4 & 4 & 4 \\
- on gaseous fuel & 92 & 91 & 98 & 101 & 106 \\
- on electricity & - & - & - & - & $4^{*}$ \\
\cline { 1 - 2 } Fuel consumption, thousand tons & 125.0 & 137.6 & 163.3 & 159.8 & 156.9 \\
\hline
\end{tabular}

* The data are from Report on the results of the Sevastopol Government activity in 2018 (https://sevzakon.ru/assets/files/otchety/gubernator/otchet_pravit._za_2018_god.pdf).

Tab. 4 shows that by 2018 the number of stationary heat sources of the city compared with 2014 increased from 116 to 143. At the same time, the number of boiler houses operating on solid and gaseous fuels increased. A sharp increase in the number of boiler houses occurred in 2016 (from 118 to 133), which coincides in time with a twofold growth of emissions of nitrogen oxides into the atmosphere and nitrogen flow with precipitation according to our analysis results.

Taking into account the total increase of the number of boiler houses in Sevastopol in 2018, the level of nitrogen oxide emissions from boiler houses can be expected to remain at least the same, than to increase. However, the opposite picture is observed - a sharp decrease in emissions (see Tab. 2), which is also confirmed by the oxidized nitrogen concentration values in atmospheric precipitation (see Tab. 3). A possible explanation for this may be an improvement in the system for cleaning exhaust gases from boiler houses in Sevastopol, or an improvement in the quality of fuel burned.

\section{Conclusions}

The results of the work carried out on the example of Sevastopol showed that there is a close correlation between the characteristics of stationary heat sources and the amount of oxidized forms of nitrogen in atmospheric precipitation during the heating period. With the emission increase from stationary heating sources, the nitrogen flow coming from atmospheric precipitation to the underlying surface proportionally increases. A similar situation was observed in 2015-2017. However, in 2018, the amount of nitrogen oxide emissions as a result of the operation of boiler houses significantly decreased, despite their total amount increase, which also led to an almost halved reduction in the nitrate and nitrite nitrogen flow with atmospheric precipitation. 
Taking into account that inorganic nitrogen is one of the main nutrients for marine ecosystems, it is very important to evaluate its incoming with precipitation and the sources of this income. This is especially important for coastal ecosystems that are under conditions of increased anthropogenic pressure, since the excess supply of this element can lead to disruption of their functioning.

\section{REFERENCES}

1. Mikhailov, A.G., Batrakov, P.A. and Terebilov, S.V., 2013. Problems of Heat Transfer in the Furnace of Boilers. Overview of Calculation Methods. In: A. G. Shibaev and A. D. Markova, Eds., 2013. Modern Scientific Research and Their Practical Application. Odesa: Kupriyenko SV. Vol. J21310, Article CID Number J21310-084. Available at: http://www.sworld.com.ua/e-journal/J21310.pdf [Accessed: 02 May 2020].

2. Santos, F.S., Miranda, G.A., Carvalho, A.N.M., Carvalho, V.S.B. and Albuquerque, T.T. de A., 2019. Regulated Air Pollutant Emissions from Higher Emitters Stationary Sources in Belo Horisonte, Minas Gerais, Brazil. Brazilian Journal of Chemical Engineering, 36(2), pp. 775-784. http://dx.doi.org/10.1590/01046632.20190362s20180352

3. Taylasheva, T.S., Krasil'nikova, L.G. and Vorontsova, E.S., 2013. [Estimate of the Harmful Atmospheric Emissions from Boiler Houses in the Tomsk Region]. Bulletin of the Tomsk Polytechnic University Geo Assets Engineering, 322(4), pp. $52-55$ (in Russian).

4. Nowak, K., Bukowska, M., Proszak-Miąsik, D. and Rabczak, S., 2017. Emission of Air Pollutants in the Hot Water Production. IOP Conference Series: Materials Science and Engineering, 245(5), 052032. https://doi.org/10.1088/1757899X/245/5/052032

5. Adamczyk, J., Piwowar, A. and Dzikuć, M., 2017. Air Protection Programmes in Poland in the Context of the Low Emission. Environmental Science and Pollution Research, 24(19), pp. 16316-16327. https://doi.org/10.1007/s11356-017-9233-9

6. Kaczmarczyk, M., Sowiżdżał, A. and Tomaszewska, B., 2020. Energetic and Environmental Aspects of Individual Heat Generation for Sustainable Development at a Local Scale - A Case Study from Poland. Energies, 13(2), 454. https://doi.org/10.3390/en13020454

7. Bhander, G. and Jozewicz, W., 2017. Analysis of Emission Reduction Strategies for Power Boilers in the US Pulp and Paper Industry. Energy and Emission Control Technologies, 5, pp. 27-37. https://doi.org/10.2147/EECT.S139648

8. Duce, R.A., Laroche, J., Altieri, K., Arrigo, K.R., Baker, A.R., Capone, D.G., Cornell, S., Dentener, F., Galloway, J. [et al.], 2008. Impacts Of Atmospheric Anthropogenic Nitrogen on the Open Ocean. Science, 320(5878), pp. 893-897. https://doi.org/10.1126/science.1150369

9. Paerl, H.W., 1997. Coastal Eutrophication and Harmful Algal Blooms: Importance of Atmospheric Deposition and Groundwater as "New" Nitrogen and Other Nutrient Sources. Limnology and Oceanography, 42(5), part 2, pp. 1154-1165. https://doi.org/10.4319/lo.1997.42.5_part_2.1154

10. Belokopytov, V.N., Kubryakov, A.I. and Pryakhina, S.F., 2019. Modelling of Water Pollution Propagation in the Sevastopol Bay. Physical Oceanography, 26(1), pp. 3-12. doi:10.22449/1573-160X-2019-1-3-12 
11. Nasiruddin Khan, M. and Sarwar, A., 2014. Chemical Composition of Wet Precipitation of Air Pollutants: A Case Study in Karachi, Pakistan. Atmósfera, 27(1), pp. 35-46. https://doi.org/10.1016/S0187-6236(14)71099-9

12. Varenik, A.V., 2019. Applying the Brandon Method to Estimate the Concentration of Inorganic Nitrogen in Precipitation. Russian Meteorology and Hydrology, 44(5), pp. 326-330. https://doi.org/10.3103/S1068373919050030

About the author:

Alla V. Varenik, Senior Scientist, Marine Hydrophysical Institute of RAS (2 Kapitanskaya St., Sevastopol, Russian Federation, 299011), Ph. D. (Geogr.), SPINcode: 3277-7914, ORCID ID: 0000-0001-5033-4576, ResearcherID: H-1880-2014, alla.varenik@mhi-ras.ru

The author has read and approved the final manuscript.

The author declares that she has no conflict of interest. 